\title{
KUALITAS TUMBUH KEMBANG, PENGASUHAN ORANG TUA, DAN FAKTOR RISIKO KOMUNITAS PADA ANAK USIA PRASEKOLAH WILAYAH PEDESAAN DI BOGOR
}

\author{
Quality of Child Development, Parenting, and Risk Factors of Community on \\ Preschool Children at Rural Area in Bogor District
}

\author{
MELLY LATIFAH $^{1}$, ALFIASARI $^{1 *}$, NETI HERNAWATI $^{1}$ \\ ${ }^{1}$ Staf Pengajar Departemen Ilmu Keluarga dan Konsumen, Fakultas Ekologi \\ Manusia, Institut Pertanian Bogor, Jalan Lingkar Kampus IPB Dramaga, \\ Bogor 16680
}

\begin{abstract}
Every family wants to reach qualified children in conducting of child caring. Generally, this study aims to analyze: (i) quality of child development; (ii) quality of psychosocial environment of parenting practices; and (iii) quality of family life and community that identified become risk factors to child development. This article is a part of results of multiyears study that consists of data from first year study. The design of the first study is cross sectional study that involved 208 families in rural area who had preschool children. The sites of study are four villages in two sub districts (Ciawi and Ciampea) in Bogor. The sites chosen by purposive based on the ecological context. Meanwhile, the samples are chosen by random sampling the result of this study showed that in all of study sites, only $70 \%$ of the children that had high quality of developmental task. The other result showed that there were $71,6 \%$ families in Ciawi and $64,2 \%$ in Ciampea that had moderate quality of psychosocial environment of parenting practices. The level of stress and anxiety of mother gave significant negative effect to quality of parenting. There are some factors that identified will become risk factors of community to child development such as communication low level of education, low income, and low knowledge of parenting.
\end{abstract}

Keywords: HOME, parenting, preschool children, quality of development, risk factors of community

\section{PENDAHULUAN}

Seorang anak akan mengabadikan apa yang terjadi saat ini ke masa depan yang dia miliki (Berns 1997). Usia anakanak merupakan usia yang produktif dalam perkembangan manusia. Faktor genetis (nature) dan faktor lingkungan (nurture) sangat berperan dalam mempengaruhi tumbuh kembang anak. Salah satu faktor lingkungan yang berperan sangat penting adalah kualitas pengasuhan yang diterapkan oleh orang tua. Pengasuhan erat kaitannya dengan kemampuan suatu keluarga/rumah tangga dan komunitas dalam hal memberikan perhatian, waktu, dan dukungan untuk memenuhi kebutuhan fisik, mental, dan sosial anak-anak yang sedang dalam masa pertumbuhan serta bagi anggota keluarga lainnya (ICN 1992 dalam Engle et al. 1997).

Setiap keluarga, dalam melakukan proses pengasuhan anak tentu saja bertujuan untuk mengoptimalkan pertumbuhan dan perkembangannya secara holistik. Keluarga, sekolah, komunitas, dan masyarakat bertanggung jawab untuk menyediakan lingkungan yang aman dan sehat bagi anak untuk dapat menjalani kehidupannya sebaik mungkin dan berkembang secara optimal (Berns 1997). Anak, orang tua, dan komunitas mempunyai peran penting dalam sebuah proses pengasuhan dan peran masingmasing dipengaruhi oleh peran lainnya.

Artikel ini adalah salah satu bagian dari penelitian multiyears yang berjudul "Pengembangan Model Kelembagaan Berbasis Komunitas Lokal yang Ramah 
terhadap Perkembangan Anak pada Masyarakat Pedesaan di Bogor" yang dibiayai oleh Direktorat Pendidikan Tinggi melalui Hibah Bersaing sejak tahun 2008. Hasil penelitian yang disajikan dalam artikel ini adalah sebagian dari hasil penelitian pada tahun pertama, yang merupakan data baseline sebagai dasar bagi tindak lanjut penelitian berikutnya. Tujuan penulisan artikel ini adalah menganalisis keragaan beberapa variabel pokok dalam penelitian tersebut yang mencakup: (1) karakteristik keluarga (besar keluarga, pendidikan orang tua, pendapatan keluarga, komunikasi di dalam keluarga, dan nilai anak); (2) kualitas tumbuh kembang anak usia prasekolah (motorik, bahasa, kognitif, kemampuan menolong diri sendiri, sosial emosi, dan moral) pada masyarakat pedesaan di lokasi penelitian; (3) kualitas lingkungan pengasuhan psikososial yang dilakukan orang tua, termasuk kelekatan ibu-anak, tingkat stres ibu, dan tingkat kecemasan ibu; dan (4) kualitas keluarga dan komunitas yang berisiko terhadap tumbuh kembang anak usia prasekolah di lokasi penelitian.

\section{METODE}

\section{Desain, Populasi, dan Contoh Penelitian}

Desain penelitian ini adalah cross sectional study yang mana pengukuran variabel penelitian dilakukan dalam satu kali pengukuran. Populasi penelitian ini adalah seluruh keluarga yang mempunyai anak usia prasekolah (usia 3-6 tahun) di Kabupaten Bogor.

Penelitian ini menggabungkan metode kuantitatif dan kualitatif. Metode kuantitatif digunakan untuk menjawab tujuan (1), (2), dan (3), sedangkan metode kualitatif digunakan untuk menjawab tujuan (4).

Penelitian ini dilaksanakan di empat desa di dua kecamatan di Kabupaten Bogor. Dua kecamatan yang menjadi lokasi penelitian dipilih secara purposive berdasarkan ekologi wilayah, yaitu satu kecamatan mewakili kecamatan yang berada di daerah dataran tinggi yaitu Kecamatan Ciawi dan satu kecamatan merupakan representasi dari daerah dataran rendah yaitu Kecamatan Ciampea. Sementara itu, desa yang dijadikan lokasi penelitian juga dipilih secara purposive dalam kecamatan terpilih dengan pertimbangan utama yaitu merupakan desa dengan keadaan perekonomian yang rendah dan merupakan wilayah asli pedesaan di kecamatan terpilih. Desa yang terpilih adalah Jambuluwuk dan Desa Bojongmurni di Kecamatan Ciawi; serta Desa Cinangka dan Desa Bojong Jengkol di Kecamatan Ciampea.

Dari masing-masing desa dipilih 50 keluarga contoh yang mempunyai anak prasekolah di masing-masing desa terpilih, sehingga terpilih secara acak 200 keluarga contoh. Namun, untuk menghindari terjadinya ketidaklengkapan data ketika proses pengolahan data maka jumlah keluarga contoh yang diambil di masing-masing desa adalah 53. Namun karena ada beberapa data keluarga contoh yang tidak lengkap maka jumlah total keluarga contoh penelitian ini menjadi 208.

\section{Jenis, Teknik, dan Cara Pengumpulan Data}

Jenis data yang dikumpulkan dalam penelitian ini adalah data primer dan data sekunder. Data primer dikumpulkan dengan beberapa teknik yaitu melalui:

1. Wawancara dengan keluarga menggunakan kuesioner yang telah disiapkan, untuk mengidentifikasi karakteristik keluarga dan lingkungan pengasuhan.

2. Penilaian tumbuh kembang anak usia prasekolah dalam keluarga contoh dengan menggunakan instrumen kuesioner.

3. Focus Group Discussion dan wawancara mendalam (indepth interview) terhadap beberapa keluarga dan tokoh masyarakat terpilih, untuk mengidentifikasikan faktor risiko yang ada di dalam keluarga dan komunitas terhadap perkembangan anak.

Selain data primer, penelitian ini juga menggunakan data sekunder dari instansi-instansi terkait untuk menunjang analisis data primer yang dihasilkan dalam penelitian ini.

\section{Pengolahan dan Analisis Data}

Data kuantitatif yang diperoleh akan diolah melalui proses editing, coding, scoring, entry data ke komputer, cleaning data, dan analisis data. Data dianalisis 
secara deskriptif menggunakan rata-rata dan tabulasi silang, serta analisis inferensia statistika (uji korelasi dan uji regresi linear). Data diolah dengan menggunakan Microsoft Excel dan SPSS versi 10.0 for windows.

\section{HASIL DAN PEMBAHASAN}

\section{Karakteristik Keluarga dan Karakteristik Komunitas}

Responden penelitian ini berjumlah 208 keluarga yang mempunyai anak usia prasekolah (3-5 tahun). Bila ditinjau dari besar keluarga, hasil penelitian ini menunjukkan bahwa kedua kecamatan lokasi penelitian menunjukkan keragaman yang sama, yang mana sebagian besar keluarga merupakan keluarga kecil dengan jumlah anggota masing-masing keluarga paling banyak 4 orang $(42,2 \%$ di Kecamatan Ciawi dan $37,7 \%$ di Kecamatan Ciampea). Berdasarkan data yang diperoleh, jumlah anggota keluarga di kedua lokasi penelitian tidak terlalu besar dan sebagian besar keluarga mempunyai kepadatan di dalam rumahnya berada dalam kategori $<5$ orang $/ \mathrm{m}^{2}$ (41,2\% di Kecamatan Ciawi dan $55,7 \%$ di Kecamatan Ciampea).

Sementara itu, berdasarkan tingkat pendidikan KK dan ibu, kondisi di kedua kecamatan menunjukkan keadaan yang tidak jauh berbeda yang mana tingkat pendidikannya masih rendah. Sebagian besar KK mempunyai pendidikan paling tinggi adalah tamat SD/sederajat $(37,3 \%$ di Kecamatan Ciawi dan 54,7\% di Kecamatan Ciampea). Begitu juga pendidikan ibu, sebagian besar ibu di kedua lokasi penelitian mempunyai pendidikan paling tinggi tamat SD/sederajat dan tidak tamat SD/sederajat. Berdasarkan kondisi ekonomi keluarga, sebagian besar pendapatan per kapita per bulan keluarga contoh berada dalam kategori miskin (berdasarkan garis kemiskinan BPS 2006), yaitu di bawah Rp 152.847,00 per kapita per bulan $(54,9 \%$ di Kecamatan Ciawi dan 46,2\% di Kecamatan Ciampea).

Salah satu faktor yang menentukan kualitas kehidupan keluarga, selain kondisi sosial demografis dan ekonomi, adalah kehidupan psikologis dalam keluarga. Berdasarkan data yang diperoleh, sebagian besar keluarga contoh mempunyai tingkat komunikasi yang baik di dalam keluarga $(58,8 \%$ di Kecamatan Ciawi dan 78,3\% di Kecamatan Ciampea). Begitu juga perlakuan suami kepada istri ataupun sebaliknya dimana di kedua lokasi penelitian juga masuk dalam kategori tinggi. Hasil ini menunjukkan bahwa keluarga contoh sudah mempunyai modal kondisi kehidupan psikologis keluarga yang baik. Hal ini tentu saja merupakan keuntungan bagi keluarga apabila ada program-program intervensi yang bertujuan untuk meningkatkan kualitas keluarga.

Begitu juga dengan persepsi nilai anak dari keluarga contoh yang menunjukkan bahwa sebagian besar keluarga contoh mempunyai persepsi nilai anak baik secara ekonomi, sosial, dan psikologi yang tinggi $(88,2 \%$ di Kecamatan Ciawi dan 99,1\% di Kecamatan Ciampea). Kondisi ini juga merupakan keuntungan bagi keluarga karena nilai anak sebagai salah satu komponen input dalam proses manajemen sumberdaya keluarga mempunyai nilai yang tinggi. Sehingga modal awal bagi keluarga untuk melakukan proses manajemen yang baik guna meningkatkan kualitas anak telah tersedia di dalam keluarga.

Dalam penelitian ini, komunitas yang merujuk pada dusun atau beberapa RT yang berdekatan juga diamati tentang bagaimana dukungan yang diberikan terhadap perkembangan yang optimal bagi anak. Berdasarkan pengamatan yang dilakukan di lapang, kehidupan bertetangga di keempat desa lokasi penelitian masih cukup tinggi kebersamaannya. Hal ini terlihat dari pengakuan tokoh masyarakat dan juga beberapa penduduk bahwa gotong royong masih muncul di wilayah pedesaan yang menjadi lokasi penelitian ini. Sebagian besar KK di lokasi penelitian berasal dari Suku Sunda $(91,2 \%$ di Kecamatan Ciawi dan 96,2\% di Kecamatan Ciampea).

Sesuai dengan data sekunder yang diperoleh dari pihak desa, keempat desa lokasi penelitian mempunyai penduduk yang sebagian besar adalah petani, yang mana porsi terbesar adalah merupakan petani penggarap. Kondisi ini mencerminkan bahwa kondisi sosial ekonomi anggota komunitas tergolong pada golongan ekonomi menengah ke bawah. 
Sementara itu, keyakinan (beliefs) tentang anak di desa ini menunjukkan bahwa harapan masyarakat, anak-anak dapat tumbuh dan berkembang secara optimal dan memperoleh pendidikan hingga tingkatan setinggi-tingginya. Namun, karena keterbatasan kondisi ekonomi sebagian besar penduduk serta sarana pendidikan yang terbatas di keempat wilayah pedesaan contoh harapan itu tidak dapat terpenuhi. Sehingga keyakinan tertinggi yang dimiliki oleh sebagian besar masyarakat adalah bahwa anak mereka dengan tingkat pendidikan yang rendah hanya dapat menjadi buruh pabrik ataupun tukang ojeg yang saat ini menjadi pekerjaan alternatif di luar sektor pertanian di keempat desa lokasi contoh.

Dalam kerangka pendidikan anak usia dini, berdasarkan hasil FGD dan indepth interview menunjukkan bahwa pendidikan anak (khususnya anak usia dini) adalah tanggung jawab orang tua dan juga pemerintah. Masyarakat secara umum, khususnya pada tingkat komunitas, belum mempunyai kesadaran maupun kemauan untuk bekerjasama dengan pihak orang tua dan pemerintah desa guna mengembangkan kelembagaan pendidikan anak usia dini, sebagai sebuah perwujudan penciptaan lingkungan komunitas yang ramah anak.

Anak tumbuh dan berkembang melalui proses interaktif antara dirinya dengan lingkungannya sebagai sebuah ekosistem. Dalam ekosistem tersebut, terdapat berbagai faktor baik faktor alami, fisik, kimia, biologi, sosiobudaya, dan ekologi yang saling berinteraksi dan mempengaruhi proses tumbuh kembang seorang anak. Berbagai faktor tersebut baik dari keluarga maupun komunitas dapat mempengaruhi pertumbuhan dan perkembangan anak, baik menjadi faktor yang bersifat mendukung maupun menghambat.

Hasil observasi, FGD, maupun indepth interview menunjukkan bahwa di keempat desa lokasi penelitian mempunyai keragaan yang sama dalam hal interaksi komunitas, keluarga, dan anak dalam ruang lingkup pertumbuhan dan perkembangan anak, khususnya anak usia prasekolah. Di keempat desa lokasi penelitian, ditemukan persepsi yang muncul secara umum mulai dari tingkat aparat desa, tokoh masyarakat, tenaga pendidik Kelembagaan Pendidikan Anak Usia Dini, maupun orang tua, bahwa pertumbuhan dan perkembangan anak yang optimal merupakan tanggung jawab orang tua. Hal ini menunjukkan belum adanya kesadaran di tingkat komunitas bahwa untuk mampu menciptakan generasi penerus yang berkualitas diperlukan upaya bersama mulai dari aparat desa, tokoh masyarakat, tokoh pendidikan, maupun orang tua.

Karakteristik keluarga dan komunitas yang telah diuraikan menunjukkan bahwa kesadaran dan kemauan komunitas sebagai salah satu pihak yang berpengaruh untuk dapat mewujudkan kualitas generasi masa depan masih belum ada. Oleh karenanya, perlu ada intervensi di tingkat komunitas untuk mendukung komunitas agar memberikan lingkungan yang kondusif, sehingga keluarga dapat terbantu untuk mengoptimalkan tumbuh kembang anaknya.

\section{Kualitas Perkembangan Anak}

Secara umum, hasil penelitian ini menunjukkan bahwa tingkat perkembangan anak di Kecamatan Ciawi dan Ciampea relatif sama, di mana hanya sekitar $70 \%$ anak prasekolah saja yang tingkat perkembangannya baik. Sementara itu, tingkat perkembangan anak prasekolah sisanya termasuk kategori sedang, bahkan sekitar 3\% di Kecamatan Ciawi dan $2 \%$ di Kecamatan Ciampea termasuk kategori kurang (Tabel 2). Hal ini menggambarkan bahwa perkembangan sekitar $30 \%$ anak prasekolah di kedua wilayah tersebut tidak optimal. Kondisi ini cukup memprihatinkan mengingat bahwa masa usia dini merupakan usia emas perkembangan anak yang akan menjadi fondasi bagi perkembangan selanjutnya (Hurlock 1978). Oleh karena itu, kondisi ini perlu mendapat perhatian dan penanganan segera dari berbagai pihak, baik orang tua, masyarakat, pemerintah daerah, serta pihak swasta. 
Tabel 1. Sebaran anak contoh berdasarkan kualitas perkembangan anak

\begin{tabular}{|c|c|c|c|c|c|c|}
\hline \multirow{2}{*}{$\begin{array}{c}\text { Kecamatan } \\
\text { lokasi }\end{array}$} & \multirow{2}{*}{\multicolumn{2}{|c|}{ Desa lokasi }} & \multicolumn{3}{|c|}{ Kualitas Perkembangan Anak } & \multirow{2}{*}{ Total } \\
\hline & & & Kurang & Sedang & Baik & \\
\hline \multirow{6}{*}{ Ciawi } & \multirow{2}{*}{ Bojongmurni } & $\mathrm{n}$ & 0 & 11 & 41 & 52 \\
\hline & & $\%$ & 0,0 & 21,2 & 78,8 & 100,0 \\
\hline & \multirow{2}{*}{ Jambuluwuk } & $\mathrm{n}$ & 3 & 17 & 30 & 50 \\
\hline & & $\%$ & 6,0 & 34,0 & 60,0 & 100,0 \\
\hline & \multirow{2}{*}{ Total } & $\mathbf{n}$ & 3 & 28 & 71 & 102 \\
\hline & & $\%$ & 2,9 & 27,5 & 69,6 & 100,0 \\
\hline \multirow{6}{*}{ Ciampea } & \multirow{2}{*}{ Bojongjengkol } & $\mathrm{n}$ & 1 & 14 & 39 & 54 \\
\hline & & $\%$ & 1,9 & 25,9 & 72,2 & 100,0 \\
\hline & \multirow{2}{*}{ Cinangka } & $\mathrm{n}$ & 1 & 16 & 35 & 52 \\
\hline & & $\%$ & 1,9 & 30,8 & 67,3 & 100,0 \\
\hline & \multirow{2}{*}{ Total } & $\mathbf{n}$ & 2 & 30 & 74 & 106 \\
\hline & & $\%$ & 1,9 & 28,3 & 69,8 & 100,0 \\
\hline
\end{tabular}

Kualitas Perkembangan Motorik Kasar dan Motorik Halus. Hasil penelitian di Kecamatan Ciawi dan Ciampea menunjukkan bahwa sekitar $90 \%$ anak prasekolah di kedua kecamatan tersebut memiliki tingkat perkembangan motorik kasar yang baik, sementara itu sisanya memiliki tingkat perkembangan motorik kasar kategori sedang, dan tidak satu pun yang termasuk kategori kurang. Berbeda dengan tingkat perkembangan motorik kasarnya, tingkat perkembangan motorik halus anak usia prasekolah di kedua kecamatan ini kurang menggembirakan. Hanya sekitar $60 \%$ anak usia prasekolah di Kecamatan Ciawi dan sekitar $70 \%$ di Kecamatan Ciampea yang tingkat perkembangan motorik halusnya baik. Sementara itu, tingkat perkembangan motorik anak prasekolah sisanya termasuk kategori sedang.

Kualitas Perkembangan Bahasa. Hasil penelitian menunjukkan bahwa tingkat perkembangan bahasa anak prasekolah di Kecamatan Ciawi dan Ciampea hanya sekitar $50 \%$ saja yang baik. Sementara sisanya termasuk kategori sedang, bahkan sekitar $6 \%$ anak di Kecamatan Ciawi dan 7,5\% di Kecamatan Ciampea memiliki tingkat perkembangan bahasa kategori kurang.

Kualitas Perkembangan Kognitif. Berdasarkan hasil penelitian diketahui bahwa kurang dari $60 \%$ anak di Kecamatan Ciawi dan Ciampea memiliki tingkat perkembangan kognitif baik. Sementara itu, lebih dari $40 \%$ anak memiliki tingkat perkembangan kognitif sedang, bahkan sekitar $4 \%$ anak di Kecamatan Ciawi dan $1 \%$ anak di Kecamatan Ciampea memiliki tingkat perkembangan kognitif kurang. Padahal telah dijelaskan bahwa kemampuan kognitif sangat penting karena berkaitan dengan kualitas manusia, khususnya dalam kemampuan berkomunikasi, belajar, bekerja, serta kemampuan memecahkan berbagai masalah. Kondisi lingkungan yang tidak menguntungkan, seperti asupan gizi yang kurang, perawatan kesehatan yang tidak memadai serta stimulasi psikososial yang seadanya (Myer 1992) dapat menjadi penyebab rendahnya tingkat perkembangan kognitif anak-anak di Kecamatan Ciawi dan Ciampea. Kondisi sosial ekonomi yang tidak memadai, seperti pendidikan dan pendapatan keluarga yang rendah merupakan faktor yang mungkin menjadi penyebab kondisi yang tidak menguntungkan tersebut.

Kualitas Kemampuan Menolong Diri Sendiri. Hasil penelitian menunjukkan bahwa lebih dari 75\% anak dari Kecamatan Ciawi dan lebih dari 85\% anak dari Kecamatan Ciampea memiliki kemampuan menolong diri sendiri kategori baik. Sementara itu sisanya, yaitu $23,5 \%$ anak dari Kecamatan Ciawi dan 10,4\% anak dari Kecamatan Ciampea, memiliki kemampuan menolong diri sendiri kategori sedang, dan 1,9\% anak dari Kecamatan Ciampea termasuk kategori kurang. Akan tetapi, tidak satu pun anak dari Kecamatan Ciawi yang termasuk kategori kurang.

Kualitas Kematangan Sosial dan Emosi. Hampir sama dengan kemampuan menolong diri sendiri, tingkat kematangan sosial dan emosi anak di Kecamatan Ciawi dan Ciampea juga relatif baik. Hal ini dapat dilihat dari banyaknya anak yang memiliki tingkat 
kematangan sosial kategori baik $(86,3 \%$ di Ciawi dan $89,6 \%$ di Ciampea) dan tidak satu pun anak di kedua kecamatan tersebut yang memiliki tingkat kematangan sosial kategori kurang. Sementara untuk kematangan emosi, diketahui bahwa kematangan emosi anak di Kecamatan Ciampea lebih baik dari anak di Kecamatan Ciawi. Hal ini dapat dilihat dari persentase anak yang memiliki tingkat kematangan emosi tinggi di Kecamatan Ciampea jauh lebih banyak $(80,2 \%)$ dari Kecamatan Ciawi $(21,6 \%)$. Sementara itu, tingkat kematangan emosi di Kecamatan Ciawi lebih banyak pada kategori sedang.

Kualitas Perkembangan Moral. Seperti halnya tingkat perkembangan motorik halus, bahasa dan kognitif, tingkat perkembangan moral anak di kedua wilayah penelitian juga memprihatinkan, bahkan lebih buruk dari ketiga aspek perkembangan itu. Hasil penelitian menunjukkan bahwa tingkat perkembangan moral anak mengumpul pada kategori sedang dan rendah (hampir $80 \%$ anak di Ciawi dan Ciampea).

\section{Praktek Pengasuhan Keluarga}

Kualitas Pengasuhan. Home Observation for Measurement of the Environment (HOME) merupakan instrumen untuk mengukur kualitas pengasuhan yang dilakukan oleh pengasuh terhadap anak. Hasil penelitian menunjukkan bahwa kualitas pengasuhan di kedua kecamatan lokasi penelitian berada pada kategori sedang, dengan persentase masing-masing $71,6 \%$ dan $64,2 \%$. Di Kecamatan Ciawi, tidak ada satu pun ibu/pengasuh yang memberikan kualitas pengasuhan dengan kategori tinggi, sedangkan di Kecamatan Ciampea hanya terdapat satu ibu/pengasuh $(0,9 \%)$. Persentase terbesar $(46,3 \%)$ ibu/pengasuh yang melakukan pengasuhan dengan kualitas rendah berada di Desa Bojongjengkol, Kecamatan Ciampea (Tabel 2). Hal ini juga sejalan dengan temuan Alfiasari et al. (2008) di Kelurahan Tajur, Kota Bogor, yang mana terdapat $72,7 \%$ rumah tangga miskin yang mempunyai lingkungan pengasuhan kualitas rendah yang diterapkan pada anak balitanya.

Stimulasi belajar merupakan subskala pertama dari instrumen HOME untuk usia 3-6 tahun. Dari hasil penelitian didapatkan bahwa stimulasi belajar pada contoh di kedua kecamatan berada pada kategori rendah, dengan persentase masing-masing sebesar $69,6 \%$ untuk Kecamatan Ciawi dan 62,3\% untuk Kecamatan Ciampea. Meskipun secara umum persentase contoh yang berada pada kategori rendah terdapat di Kecamatan Ciawi, namun jika dirinci berdasarkan desa maka persentase terbesar contoh yang berada pada kategori rendah terdapat di Desa Bojongjengkol, Kecamatan Ciampea $(83 \%)$.

Stimulasi bahasa diperlukan oleh anak untuk meningkatkan perkembangan berbahasa dan komunikasi. Berdasarkan hasil penelitian diketahui bahwa stimulasi bahasa yang diberikan oleh ibu/pengasuh kepada anak di keempat desa lokasi penelitian masih sangat rendah. Hal ini dibuktikan dengan fakta bahwa tidak ada satu pun contoh yang berada pada kategori sedang atau tinggi dalam hal pemberian stimulasi bahasa, sehingga dipastikan $100 \%$ contoh memberikan stimulasi bahasa kepada anak dengan kualitas yang masih rendah.

Penyediaan lingkungan fisik merupakan penyediaan lingkungan yang memenuhi kebutuhan fisik dasar dan pemenuhan kebutuhan kesehatan dan keselamatan bagi anak. Lingkungan fisik yang nyaman dan aman mutlak diperlukan oleh seorang anak agar dapat berkembang dengan baik. Hasil penelitian menunjukkan bahwa terdapat perbedaan kualitas lingkungan fisik antara contoh di Kecamatan Ciawi dan Ciampea. Di Kecamatan Ciawi, persentase terbesar contoh memiliki lingkungan fisik dengan kualitas yang tinggi (52\%), sedangkan persentase terbesar contoh di Kecamatan Ciampea memiliki lingkungan fisik dengan kualitas yang sedang $(41,5 \%)$.

Subskala keempat dari instrumen HOME adalah kehangatan dan penerimaan. Hasil penelitian menunjukkan bahwa pada umumnya contoh memberikan kehangatan dan menerima anak dengan baik. Hal ini terlihat dari persentase terbesar contoh di kedua kecamatan untuk subskala ini berada pada kategori tinggi, yaitu $79 \%$ untuk Kecamatan Ciawi dan 79,2\% untuk Kecamatan Ciampea. 
Tabel 2. Sebaran anak contoh berdasarkan skor total HOME

\begin{tabular}{|c|c|c|c|c|c|c|}
\hline \multirow{2}{*}{ Kecamatan Lokasi } & \multirow{2}{*}{\multicolumn{2}{|c|}{ Desa Lokasi }} & \multicolumn{3}{|c|}{ Kategori Skor HOME } & \multirow{2}{*}{ Total } \\
\hline & & & Rendah & Sedang & Tinggi & \\
\hline \multirow{6}{*}{ Ciawi } & \multirow{2}{*}{ Bojongmurni } & $\mathrm{n}$ & 12 & 40 & 0 & 52 \\
\hline & & $\%$ & 23,1 & 76,9 & 0,0 & 100,0 \\
\hline & \multirow{2}{*}{ Jambuluwuk } & $\mathrm{n}$ & 17 & 33 & 0 & 50 \\
\hline & & $\%$ & 34,0 & 66,0 & 0,0 & 100,0 \\
\hline & \multirow{2}{*}{ Total } & $\mathbf{n}$ & 29 & 73 & 0 & 102 \\
\hline & & $\%$ & 28,4 & 71,6 & 0,0 & 100,0 \\
\hline \multirow{6}{*}{ Ciampea } & \multirow{2}{*}{ Bojongjengkol } & $\mathrm{n}$ & 25 & 29 & 0 & 54 \\
\hline & & $\%$ & 46,3 & 53,7 & 0,0 & 100,0 \\
\hline & \multirow{2}{*}{ Cinangka } & $\mathrm{n}$ & 12 & 39 & 1 & 52 \\
\hline & & $\%$ & 23,1 & 75,0 & 1,9 & 100,0 \\
\hline & \multirow{2}{*}{ Total } & $\mathbf{n}$ & 37 & 68 & 1 & 106 \\
\hline & & $\%$ & 34.9 & 64.2 & 0.9 & 100.0 \\
\hline
\end{tabular}

Stimulasi akademik diperlukan oleh seorang anak agar dapat mencapai perkembangan kognitif yang optimal. Berdasarkan hasil penelitian diketahui bahwa terdapat perbedaan kualitas stimulasi akademik yang diberikan oleh ibu/pengasuh kepada anak di kedua kecamatan. Persentase terbesar ibu/pengasuh di Kecamatan Ciawi memberikan stimulasi akademik dengan kualitas tinggi $(59,8 \%)$. Hal berbeda terjadi di Kecamatan Ciampea. Secara umum persentase terbesar kualitas stimulasi akademik yang diberikan oleh ibu/pengasuh di Kecamatan Ciampea berada pada kategori sedang $(51,9 \%)$.

Subskala lain yang diukur dalam HOME adalah modeling. Hasil penelitian menunjukkan bahwa kualitas modeling pada contoh di kedua kecamatan masih berada pada kategori rendah. Variasi pengalaman merupakan komponen lain dari proses pengasuhan yang diperlukan oleh anak untuk mendukung perkembangannya. Hasil penelitian menunjukkan bahwa variasi pengalaman yang diberikan oleh ibu/pengasuh kepada anak di Kecamatan Ciawi berada pada kategori tinggi dengan persentase sebesar $52 \%$. Berbeda halnya dengan kondisi di Kecamatan Ciampea. Sebagian besar contoh di Kecamatan Ciampea memberikan variasi pengalaman dengan kualitas yang rendah $(55,7 \%)$.

Subskala terakhir dari HOME adalah penerimaan. Dalam hal penerimaan yang dimaksud adalah seberapa besar ibu/pengasuh menerima kehadiran dan perilaku anak. Hasil penelitian menunjukkan bahwa secara umum penerimaan ibu/pengasuh terhadap anak di kedua kecamatan berada pada kategori tinggi, dengan persentase masing-masing sebesar 60,8\% untuk Kecamatan Ciawi dan 85,1\% untuk Kecamatan Ciampea.

Attachment (Kelekatan). Attachment (kelekatan) didefinisikan sebagai ikatan afeksional yang kuat antara anak dan ibu/pengasuh utamanya (Ainsworth et al. 1978 dalam Kennedy 2004). Ikatan afeksional tersebut memiliki kualitas emosi yang khusus, yang ditunjukkan tidak hanya dengan perasaan tertekan pada anak ketika berpisah dengan ibu/pengasuhnya dan perasaan gembira ketika bertemu kembali, tetapi juga rasa aman yang dirasakan anak yang berasal dari kehadiran ibu/pengasuhnya.

Berdasarkan hasil penelitian ini, seperti yang tersaji pada Tabel 3 diketahui bahwa kualitas attachment yang terbentuk antara anak dan ibu/pengasuh di Kecamatan Ciawi secara umum berada pada kategori insecure resistant $(39,2 \%)$, meskipun perbedaan persentase untuk ketiga kategori juga tidak terlalu besar, yaitu $26,5 \%$ untuk kategori insecure avoidant dan 34,3\% untuk kategori secure. Berbeda halnya dengan kondisi di Kecamatan Ciampea. Secara umum kualitas attachment antara anak dan ibu/pengasuh di Kecamatan Ciampea berada pada kategori secure $(37,7 \%)$. 
Tabel 3. Sebaran contoh berdasarkan kualitas attachment

\begin{tabular}{|c|c|c|c|c|c|c|}
\hline \multirow[b]{2}{*}{$\begin{array}{l}\text { Kecamatan } \\
\text { Lokasi }\end{array}$} & \multirow[b]{2}{*}{ Desa Lokasi } & & \multicolumn{3}{|c|}{ Total Skor Attachment } & \multirow[b]{2}{*}{ Total } \\
\hline & & & $\begin{array}{l}\text { Insecure } \\
\text { Avoidant }\end{array}$ & $\begin{array}{l}\text { Insecure } \\
\text { Resistant }\end{array}$ & Secure & \\
\hline \multirow{6}{*}{ Ciawi } & \multirow{2}{*}{ Bojongmurni } & $\mathrm{n}$ & 16 & 18 & 18 & 52 \\
\hline & & $\%$ & 30,8 & 34,6 & 34,6 & 100,0 \\
\hline & \multirow{2}{*}{ Jambuluwuk } & $\mathrm{n}$ & 11 & 22 & 17 & 50 \\
\hline & & $\%$ & 22,0 & 44,0 & 34,0 & 100,0 \\
\hline & \multirow{2}{*}{ Total } & $\mathbf{n}$ & 27 & 40 & 35 & 102 \\
\hline & & $\%$ & 26,5 & 39,2 & 34,3 & 100,0 \\
\hline \multirow{6}{*}{ Ciampea } & \multirow{2}{*}{ Bojongjengkol } & $\mathrm{n}$ & 26 & 18 & 10 & 54 \\
\hline & & $\%$ & 48,1 & 33,3 & 18,5 & 100,0 \\
\hline & \multirow{2}{*}{ Cinangka } & $\mathrm{n}$ & 6 & 16 & 30 & 52 \\
\hline & & $\%$ & 11,5 & 30,8 & 57,7 & 100,0 \\
\hline & \multirow{2}{*}{ Total } & $\mathbf{n}$ & 32 & 34 & 40 & 106 \\
\hline & & $\%$ & 30,2 & 32,1 & 37,7 & 100,0 \\
\hline
\end{tabular}

Tingkat Stres dan Kecemasan Ibu/Pengasuh. Berdasarkan hasil penelitian diketahui bahwa sebagian besar ibu/pengasuh di Kecamatan Ciawi mengalami stres sedang, dengan persentase sebesar $78,4 \%$. Lain halnya dengan ibu/pengasuh yang ada di Kecamatan Ciampea, sebagian besar dari mereka mengalami stres tingkat tinggi dengan persentase sebesar 56,6\% (Tabel 4).

Seperti halnya stres, kecemasan yang dialami ibu/pengasuh juga dapat berdampak negatif terhadap kualitas pengasuhan. Ibu/pengasuh yang berada dalam kondisi cemas tidak dapat melakukan praktek pengasuhan yang baik kepada anak. Hasil penelitian menunjukkan bahwa tingkat kecemasan yang dialami oleh sebagian besar ibu/pengasuh di kedua kecamatan berada pada kategori sedang, dengan persentase sebesar $71,6 \%$ untuk Kecamatan
Ciawi dan $65,1 \%$ untuk Kecamatan Ciampea (Tabel 5).

\section{Faktor Risiko dalam Perkembangan} Anak

Dalam masa pertumbuhan dan perkembangan anak, banyak faktor yang mempengaruhinya. Soetjiningsih (1995) menyebutkan beberapa faktor yang mempengaruhi pertumbuhan dan perkembangan anak, yaitu: (a) faktor genetis yang merupakan modal dasar dalam mencapai hasil akhir proses tumbuh kembang anak; dan (b) faktor lingkungan yang meliputi faktor lingkungan pranatal (sebelum lahir) dan faktor lingkungan post natal (setelah lahir). Faktor lingkungan post natal mencakup : (a) lingkungan biologis, (b) lingkungan fisik, antara lain: cuaca, sanitasi, keadaan rumah, dan radiasi, (c) lingkungan psikososial, dan (d) faktor keluarga dan adat istiadat.

Tabel 4. Sebaran contoh berdasarkan tingkat stres ibu/pengasuh

\begin{tabular}{|c|c|c|c|c|c|c|}
\hline \multirow{2}{*}{ Kecamatan Lokasi } & \multirow{2}{*}{\multicolumn{2}{|c|}{ Desa Lokasi }} & \multicolumn{3}{|c|}{ Tingkat Stres ibu/pengasuh } & \multirow{2}{*}{ Total } \\
\hline & & & Rendah & Sedang & Tinggi & \\
\hline \multirow{6}{*}{ Ciawi } & \multirow{2}{*}{ Bojongmurni } & $\mathrm{n}$ & 0 & 32 & 20 & 52 \\
\hline & & $\%$ & 0,0 & 61,5 & 38,5 & 100,0 \\
\hline & \multirow{2}{*}{ Jambuluwuk } & $\mathrm{n}$ & 2 & 48 & 0 & 50 \\
\hline & & $\%$ & 4,0 & 96,0 & 0,0 & 100,0 \\
\hline & \multirow{2}{*}{ Total } & $\mathbf{n}$ & 2 & 80 & 20 & 102 \\
\hline & & $\%$ & 2,0 & 78,4 & 19,6 & 100,0 \\
\hline \multirow{6}{*}{ Ciampea } & \multirow{2}{*}{ Bojongjengkol } & $\mathrm{n}$ & 0 & 22 & 32 & 54 \\
\hline & & $\%$ & 0,0 & 40,7 & 59,3 & 100,0 \\
\hline & \multirow{2}{*}{ Cinangka } & $\mathrm{n}$ & 0 & 24 & 28 & 52 \\
\hline & & $\%$ & 0,0 & 46,2 & 53,8 & 100,0 \\
\hline & \multirow{2}{*}{ Total } & $\mathbf{n}$ & 0 & 46 & 60 & 106 \\
\hline & & $\%$ & 0,0 & 43,4 & 56,6 & 100,0 \\
\hline
\end{tabular}


Tabel 5. Sebaran contoh berdasarkan tingkat kecemasan ibu/pengasuh

\begin{tabular}{|c|c|c|c|c|c|c|}
\hline \multirow{2}{*}{$\begin{array}{c}\text { Kecamatan } \\
\text { lokasi }\end{array}$} & \multirow{2}{*}{\multicolumn{2}{|c|}{ Desa lokasi }} & \multicolumn{3}{|c|}{ Tingkat kecemasan ibu/pengasuh } & \multirow{2}{*}{ Total } \\
\hline & & & Rendah & Sedang & Tinggi & \\
\hline \multirow{6}{*}{ Ciawi } & \multirow{2}{*}{ Bojongmurni } & $\mathrm{n}$ & 2 & 37 & 13 & 52 \\
\hline & & $\%$ & 3,8 & 71,2 & 25,0 & 100,0 \\
\hline & \multirow{2}{*}{ Jambuluwuk } & $\mathrm{n}$ & 8 & 36 & 6 & 50 \\
\hline & & $\%$ & 16,0 & 72,0 & 12,0 & 100,0 \\
\hline & \multirow{2}{*}{ Total } & $\mathbf{n}$ & 10 & 73 & 19 & 102 \\
\hline & & $\%$ & 9,8 & 71,6 & 18,6 & 100,0 \\
\hline \multirow{6}{*}{ Ciampea } & \multirow{2}{*}{ Bojongjengkol } & $\mathrm{n}$ & 4 & 35 & 15 & 54 \\
\hline & & $\%$ & 7,4 & 64,8 & 27,8 & 100,0 \\
\hline & \multirow{2}{*}{ Cinangka } & $\mathrm{n}$ & 1 & 34 & 17 & 52 \\
\hline & & $\%$ & 1,9 & 65,4 & 32,7 & 100,0 \\
\hline & \multirow{2}{*}{ Total } & $\mathbf{n}$ & 5 & 69 & 32 & 106 \\
\hline & & $\%$ & 4,7 & 65,1 & 30,2 & 100,0 \\
\hline
\end{tabular}

Di dalam penelitian ini faktor-faktor yang dilihat dalam perkembangan anak adalah faktor lingkungan psikososial dan faktor keluarga. Uji regresi yang dilakukan terhadap variabel-variabel tersebut menunjukkan bahwa dalam konteks lingkungan psikososial, persepsi orang tua akan nilai anak memberikan pengaruh signifikan positif terhadap skor total perkembangan anak $(p<0,005)$. Sementara itu, tingkat pendidikan ibu/pengasuh juga memberikan pengaruh signifikan positif terhadap total skor perkembangan anak.

Berdasarkan data FGD dan indepth interview, diidentifikasi dan dianalisis beberapa faktor risiko yang ada di dalam keluarga dan komunitas yang dapat mempengaruhi perkembangan anak usia 3-6 tahun yang ditemukan di keempat desa, yaitu:

1. Pendidikan orang tua yang rendah, yang ditunjukkan dari sebagian besar orang tua contoh adalah mempunyai pendidikan paling tinggi tamat SD/sederajat.

2. Pendapatan keluarga yang rendah, yang ditunjukkan sebagian besar keluarga contoh yang mempunyai pendapatan di bawah garis kemiskinan BPS.

3. Pengetahuan tentang pengasuhan anak masih rendah, yang ditunjukkan dari kualitas pengasuhan anak keluarga contoh yang sebagian besar berada dalam kategori rendah dan sedang.

4. Kondisi rumah dan lingkungan fisik yang belum memadai. Hal ini ditunjukkan dari kondisi lingkungan tempat tinggal yang masih belum ideal untuk mendukung perkem- bangan anak, seperti sebagian besar keluarga responden mempunyai rumah dengan kondisi tegel kotor $(58,8 \%$ di Kecamatan Ciawi dan $44,3 \%$ di Kecamatan Ciampea), ventilasi rumah yang tertutup $(43,4 \%$ di Kecamatan Ciampea), akses sinar matahari yang kurang baik karena hanya masuk ke beberapa ruangan saja (62,3\% di Kecamatan Ciampea), serta masih ada beberapa rumah tangga yang tempat membuang sampahnya di pekarangan (lubang terbuka) tanpa diolah lebih lanjut.

5. Belum tersedianya lembaga pendidikan anak usia dini di keempat komunitas yang diteliti, sehingga kalaupun ada keinginan untuk menyekolahkan anak ke lembaga PAUD, jaraknya cukup jauh dan membutuhkan biaya transportasi. Hal ini menyebabkan keluarga yang secara ekonomi tidak mampu membiayai transportasinya terpaksa tidak menyekolahkan anak ke lembaga PAUD dan hanya bermain di sekitar rumah saja.

6. Keluarga memiliki anak balita $\geq 2$ orang, yaitu $23,1 \%$ keluarga contoh yang ditemukan dalam penelitian ini. Selama 5 tahun awal perkembangannya, seorang anak memerlukan perhatian dan stimulasi psikososial yang optimal. Kehadiran balita yang lebih dari 1 orang dalam keluarga akan membuat ibu/pengasuh kesulitan membagi waktu, perhatian, dan kasih sayang kepada anak sehingga stimulasi yang diberikan kepada anak menjadi tidak optimal. 
7. Letak geografis wilayah yang terisolir (agak sulit dijangkau), jauh kepada akses pendidikan, kesehatan, pasar dII. Kondisi ini menyebabkan terhambatnya keluarga untuk mengakses pelayanan mengenai pendidikan dan kesehatan, serta informasi mengenai tumbuh kembang anak.

8. Tingkat pendidikan masyarakat rendah. Hal ini ditunjukkan dari data sekunder di tingkat kelurahan dimana sebagian besar penduduk mempunyai tingkat pendidikan paling tinggi tamat SD/sederajat. Kondisi ini menyebabkan rendahnya pengetahuan di tingkat komunitas dan masyarakat mengenai pentingnya stimulasi dan dukungan komunitas terhadap tumbuh kembang anak.

9. Sedikitnya kader Posyandu dan kader pembangunan desa lainnya. Kader Posyandu dan kader pembangunan lainnya perlu diakui sebagai motor pembangunan manusia di pedesaan. Dengan keterbatasan, baik secara kuantitas maupun kualitas, menyebabkan tidak adanya opinion leader yang ada di dalam masyarakat yang mampu meningkatkan kapasitas warganya untuk memberikan stimulasi yang optimal terhadap perkembangan anak-anak mereka.

\section{KESIMPULAN DAN SARAN}

\section{Kesimpulan}

Hasil penelitian menunjukkan bahwa tingkat perkembangan anak di Kecamatan Ciawi dan Ciampea relatif sama yang mana terdapat sekitar 30\% anak prasekolah di kedua wilayah tersebut masih tidak optimal. Sementara itu, karakteristik keluarga dan komunitas menunjukkan bahwa kesadaran dan kemauan komunitas sebagai salah satu pihak yang berpengaruh untuk dapat mewujudkan kualitas generasi masa depan masih belum ada. Di keempat desa lokasi penelitian, ditemukan persepsi yang muncul secara umum mulai dari tingkat aparat desa, tokoh masyarakat, tenaga pendidik Kelembagaan Pendidikan Anak Usia Dini, maupun orang tua bahwa pertumbuhan dan perkembangan anak yang optimal merupakan tanggung jawab orang tua.
Hal ini menunjukkan belum adanya kesadaran di tingkat masyarakat bahwa untuk mampu menciptakan generasi penerus yang berkualitas diperlukan upaya bersama mulai dari aparat desa, tokoh masyarakat, tokoh pendidikan, maupun orang tua

Kualitas pengasuhan di kedua kecamatan lokasi penelitian berada pada kategori sedang. Sementara itu, kualitas attachment yang terbentuk antara anak dan ibu/pengasuh di Kecamatan Ciawi secara umum berada pada kategori insecure resistant meskipun perbedaan persentase untuk ketiga kategori juga tidak terlalu besar. Secara umum kualitas attachment antara anak dan ibu/pengasuh di Kecamatan Ciampea berada pada kategori secure, meskipun perbedaan persentase dengan kategori insecure avoidant dan insecure resistant juga tidak terlalu besar.

Faktor risiko yang teridentifikasi di dalam keluarga dan komunitas yang dapat mempengaruhi perkembangan anak usia 3-6 tahun yang ditemukan di keempat desa, yaitu: 1) pendidikan orang tua yang rendah, 2) pendapatan keluarga yang rendah, 3) pengetahuan tentang pengasuhan anak masih rendah, 4) kondisi rumah dan lingkungan fisik yang belum memadai, 5) belum tersedianya lembaga pendidikan anak usia dini di keempat komunitas yang diteliti, 6) keluarga memiliki anak balita $\geq 2$ orang, 7 ) letak geografis wilayah yang terisolir (agak sulit dijangkau), jauh kepada akses pendidikan, kesehatan, pasar dll, 8) tingkat pendidikan masyarakat rendah, 9) sedikitnya kader Posyandu dan kader pembangunan desa lainnya.

\section{Saran}

Berdasarkan kesimpulan yang diambil, maka saran yang diberikan dari hasil penelitian ini adalah sebagai berikut:

1. Diperlukan penguatan kapasitas pengasuh/ibu untuk mampu melakukan praktek pengasuhan yang baik, penguatan kapasitas masyarakat dalam menciptakan lingkungan yang kondusif bagi perkembangan anak, dan penguatan kapasitas calon tenaga pendidik dan tenaga kependidikan lembaga PAUD yang akan dikembangkan.

2. Dalam rangka pengembangan dan penguatan jejaring dalam 
menciptakan komunitas yang ramah terhadap perkembangan anak diperlukan kerjasama dengan berbagai pihak di luar komunitas lokasi penelitian.

3. Diperlukan penelitian lebih lanjut untuk memperdalam analisis faktorfaktor risiko, khususnya yang ada di dalam komunitas, yang dapat mempengaruhi perkembangan anak yang terindentifikasi dalam penelitian ini.

\section{UCAPAN TERIMA KASIH}

Penulis mengucapkan terima kasih kepada Departemen Pendidikan Nasional. Penelitian yang disajikan dalam tulisan ini merupakan data penelitian Hibah Bersaing (HB) tahun 2008.

\footnotetext{
* Korespondensi :

Departemen IImu Keluarga dan Konsumen

Fakutas Ekologi Manusia IPB

JI. Lingkar Kampus IPB Dramaga 16680

Telp : +62-251 8628303

Email : alfia81@gmail.com
}

\section{DAFTAR PUSTAKA}

Alfiasari, Martianto D, Dharmawan $\mathrm{AH}$. 2008. Ketahanan Pangan, Pola Pengasuhan, dan Status Gizi Balita pada Rumah Tangga Miskin. Media Gizi dan Keluarga (32): 21-31 [Juli 2008].

Berns RM. 1997. Child, Family, School, Community Social and Support. Harcourt Brace College Publishers.

Engle PL, Menon P, Haddad L. 1997. Care and Nutrition: Concepts and Measurement. International Food Policy Research Institute

Soetjiningsih. 1995. Tumbuh Kembang Anak. Jakarta: Penerbit Buku Kedokteran EGC. 